\title{
STUDENT AFFAIRS MANAGEMENT IN PESANTREN-BASED FORMAL MADRASAH
}

\author{
Baqiyatush Sholihah \\ Universitas Islam Negeri Walisongo Semarang \\ Email: baqiyatush_sholihah@walisongo.ac.id
}

\begin{abstract}
This research studied about student affairs management in Madrasah Aliyah Tajul Ulum as pesantren-based formal madrasah before the madrasah was divided into two for boys and girls (banin and banat). Management aspects here are planning, organizing, staffing, leading, and evaluating. Student affairs scopes are admission of students, orientation of new students, counseling services for students, extra-curricular and co-curricular, development of superior achievement, and tracking of alumnus. This study used qualitative method. The data gained through some techniques, they are interview, observation, and documentation. Interview was done with prominent figures such as principal, vice-principal, staffs that handle student activities, and the managers of pesantren (pengurus pondok). Those techniques are aimed to gain information to answer the research questions. First question: how is the student affairs management in Madrasah Aliyah Tajul Ulum as pesantren-based formal madrasah, the second: what are the supporting and inhibiting factors of student affairs management in Madrasah Aliyah Tajul Ulum. Based on the research, could be concluded that MATU has applied the management functions in admission of students, orientation of new students, counseling services for students, extra-curricular and co-curricular, development of superior achievement, but there is a big lack in the matter of tracking of alumnus, there is no adequate management related to alumnus. Even the supporting factors in student affairs management over there are: attractive environmental condition because there are many pesantrens among the madrasah, cooperative society among the madrasah, cooperative pesantren parties, madrasah's human resources that almost have educational back-ground of pesantren. Inhibiting factors: lack of fund, the economic level of students' parents, inadequate number of classrooms, the diversity of students' backgrounds, shortage of administrative staffs which affects student management.
\end{abstract}

Keywords: student, management, formal madrasah, pesantren. 


\section{Introduction}

There are many important components of educations. Those are curriculum and learning programs, financing, educators and academic staff, facilities and infrastructure, students, culture and educational environment, community participation and school/madrasah partnership (Minister of National Education Regulation No. 19 of 2007 on Education Management Standards by units of Elementary and Secondary Education).

Student as subject and object in education should be managed well to gain the educational objectives as formulated in National Education Regulation. Madrasah as community based education is interesting to be learned moreover if it is pesantren-based madrasah. Thus, here I tried to study that matter. The location has been selected is "Madrasah Aliyah Tajul Ulum" (MATU). This is the biggest Public Islamic senior high school in Grobogan regency. It is located in J1. Pondok Pesantren Sirojuth Tholibin, village: Brabo, subdistrict: Tanggungharjo.

MATU which is under the Tajul Ulum Foundation is located among many pesantrens, they are Pondok Pesantren Sirojuth Tholibin headed by H. Maimunah and KH. Shofi Mubarok, wife and son of KH. Ahmad Baidlowi Syamsuri, Lc., Pondok Pesantren An-Nashriyyah headed by son of KH. Abdul Wahab Idris, Pondok Pesantren At-Taufiqiyyah by KH. Mudhofir al-Hafidz, Pondok Pesantren Nahdhatush Shibyan by KH. Nurhadi, Pondok Pesantren Asy-Syafi'iyah by K. Rohwan. Those pondok pesantrens are located in village Brabo. Sirojuth Tholibin is the biggest and has been being a tower of strength toward the Tajul Ulum's policies. It is reasonable due to Sirojuth Tholibin is embryo of institutions under Tajul Ulum Foundation.

Besides pesantrens in Brabo, in the neighborhood of Brabo there are also many pesantrens. For example Pondok Pesantren Roudlotul Qur'an led by K. Abu Mansyur, Pondok Pesantren Roudlotul Muttaqin led by KH. Abdul Hamid and Pondok Pesantren Bustanul Arifin by KH. Abdul Qodir, Pondok Pesantren AlIshlah by K. Syukri Ghozali, etc.

\section{Findings and Discussion}

The division of student affairs arrages the student activities begun from the preparation of work programs until the evaluation.

Preparation of work programs done in the first of academic year. Preparation of work programs carried out at the beginning of the academic year except those related to new admissions that designed at the end of the previous academic year.

Generally, student activities organization (means the fuction of organizing in management science) can ilustrated in the such following chart.

Figure 1: "Organizing” Function in Management of Student Affairs

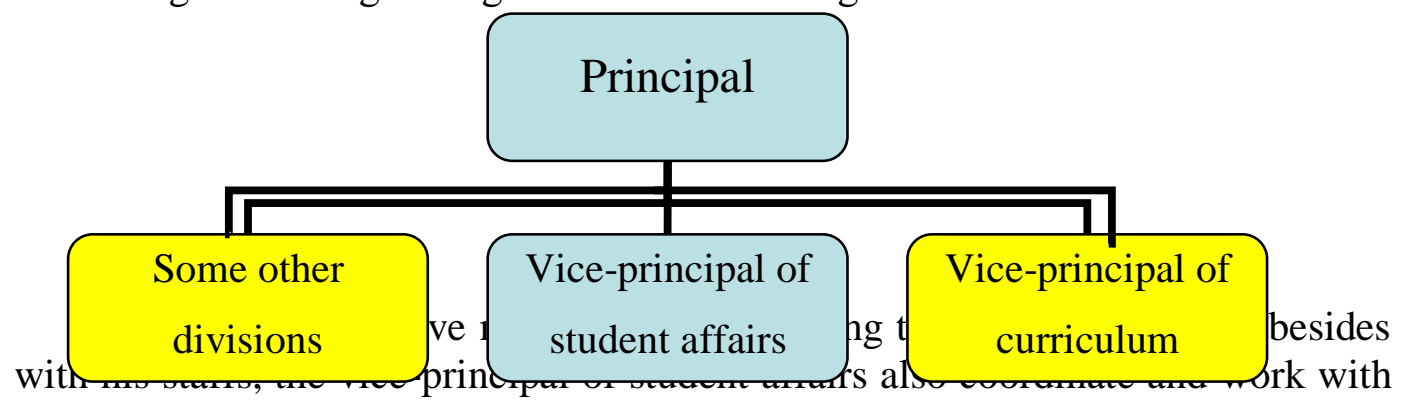


other divisions such vice-principal of curriculum, vice-principal of public relationship and so on.

In MATU, management of student affairs related to the activities of New student admissions, MOSIBA (Masa Orientasi Siswa Baru/New Student Orientation Period), Formation of New Student Council (OSIS), New student council work meeting and student council programming, Discipline entry, attributes and school uniforms, Independence Day Commemoration, Isra 'Mi'raj of Prophet Muhammad commemoration, Halal bi halal, Commemorate the birth of Prophet Muhammad (Mauludan), Visiting students who got sick and unfortunate, Poor Students Aid (BSM/Bantuan Siswa Miskin) program, Following the competition outside madrasah, Home visits to the troubled students, Scholarship Grades X, XI, XII, Following seminars outside school, Farewell of class XII, Social services, Pilgrimage (ziarah) and tourism for grade XI, Channeling student talent in the field of extracurricular, KRISTAL wall magazine, English Club, Arabic Club, Marcing Band, students' infaq, following Porseni and MAPSI Competition, Flag ceremony, events "Kamis Kliwon" (pengajian rutin Kamis Kliwon), Scouting, Basic Leadership Training (LDK) and journalism, dhuha prayer, class meeting, muwadda'ah akhirus-sanah.

Those activities arranged completely with the indicators of success, steps for achieving the success of program, responsible parties and the time frame. From the plan, it can be seen with whom the student affairs division had to coordinate, how it organized, and so on.

\section{Admission of students.}

To make the admission process well done MATU forms the committe. Committee of new student admission in MATU formed by the foundation. Means that admission is monitored centrally in Tajul Ulum Foundation. The institutions under Tajul Ulum Foundation propose the candidates of committe and the foundation people will select who are proper to hold the admission.

After the candidate filing, the foundation will provide approval or rejection. If the candidate is rejected for any reason then the institutions must propose another candidate.

In foundation the committe divided into four lines, there are: committe Madrasah Aliyah, committe of Madrasah Tsanawiyah Banin (Junior Secondary Madrasah for Male), committe of Madrasah Tsanawiyah Banat (Junior Secondary Madrasah for Female), and committe for Madrasah Diniyyah. Each line held by two person from each institution. It means that line of MATU held by persons from MATU, MTs Banin held by persons from MTs Banin, and so on. So, although centralized, each institutions representative still take care of the affairs of their respective institutions. So, according to the writer, there is centralization and decentralization here. Besides, the institusions like MATU also has right to add the committe as complementary if there is such kind of over lapping happen with the two delegations of MATU in handling the applicants (prospective students). Each person in admission committe has their own main duties and functions. Those main duties and functions given orally in meeting and also given in writing and disseminated to each member of the committee, so they have the copy.

The organization of student admission committe can be ilustrated in the following chart.

Figure 2: Student Admission Committe of Tajul Ulum Foundation 


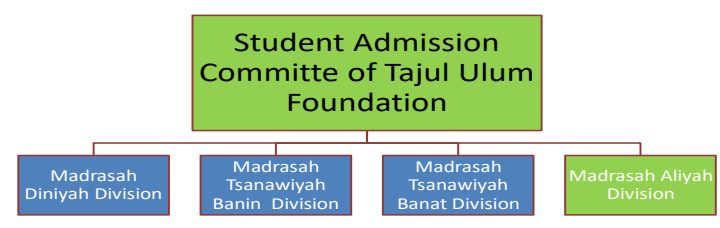

Every person in new admission committe has their own main tasks and functions, and there is written rules in this regard. So this shows that MATU has good enough planning, organizing, and coordinating related to the admission of new students. MATU follows the pillars of division of work, authority, unity of command, unity of direction, scalar of chain.

According to Suharsimi Arikunto(2008: 58-60), the tasks of student admission committe are determining the number of student that will be accepted, determining the terms of the acceptance of new students, carrying out the screening, her-registering the candidates who have been accepted, and reporting the results to the leader.

Based on interview and documentation, the committe in MATU also cover the duties as Suharsimi Arikunto presented above. After finishing the above tasks, after reporting the program actuating to the chief of foundation and the MATU principal, the student activities will be handled by vice principal of student affairs for the next activities such MOSIBA and election of a new chairman of the student council (OSIS).

\section{Criteria for prospective students}

Determining the criteria for prospective student is a part of planning in educational management. MATU gives no special criteria for students who want to study in MATU. This policy related firmly with the kiai's thought. Yai Syamsuri, the charismatic kiai of Pondok Pesantren Sirojuth Tholibin said that the institutions should not reject the students who want to learn, kiai asked to give opportuny to every person who wants to learn. (Interview with HM and other teachers).

What have said by KH. Syamsuri can be understood. However Yai Syamsuri (familiarly called by Mbah Syamsuri/Mbah Syam) is a pioneer of community-based education in Brabo and the surrounding areas, rural areas that are in desperate need of education. Especially as pesantren-based madrasah where noble character takes precedence over there, parents' hope in sending their children to Tajul Ulum usually due to close pesantren. to be in boarding schools, educated by people who close to the kiai, even well educated by many kiai directly, the students are expected to be able to imitate them. Therefore, to date Kiai Syamsuri's message still continues to hold. Moreover his son, Kiai as his father, Kiai is also a charismatic figure respected by almost all the foundations and institutionsalso always holds that message. As his father, Yai Baidlowi is also a charismatic figure that very respected by almost all the foundations and institutions.

This can be understood that kiai usually give much opportunity to every person to study in the institutions under his shelter without seeing are they low or high IQ, are they rich or poor. The people in the foundation until the institution including MATU hold this kiai's message in the matter of accepting new students.Thus, in accepting new students; MATU does not limit the number of 
them As long as the candidates follow the procedure of admission, and students will be accepted in MATU.

\section{Series of Test in Student Admission}

Although MATU does not limit the number of students and does not provide specific criteria in accepting new students, but MATU has a series of tests like in university. That series of test consisting of a written test and interview.

Although there is such kind of selection test, but it is not to determine who will accepted and who will be rejected. A set of test processes just to identify students' potencial, to know their dream, their willingness in order to make learning process easier.

In the first step, before undergoing the test, the candidates of new students must fill in the blank forms that contain information about name, hobby, goal or dream, choice of major, residence during study, transportation facilities used, phone number, and estimate of average parents' income.

The series of test has its own committe that is different from admission commitee. The committe of this test is collaboration between vice principal of student affairs, vice-principal of curricullum and coordinator of $\mathrm{BP} / \mathrm{BK}$. This coordination can be ilustrated in the following schema.

Figure 3: Coordination Schema in New Students Test

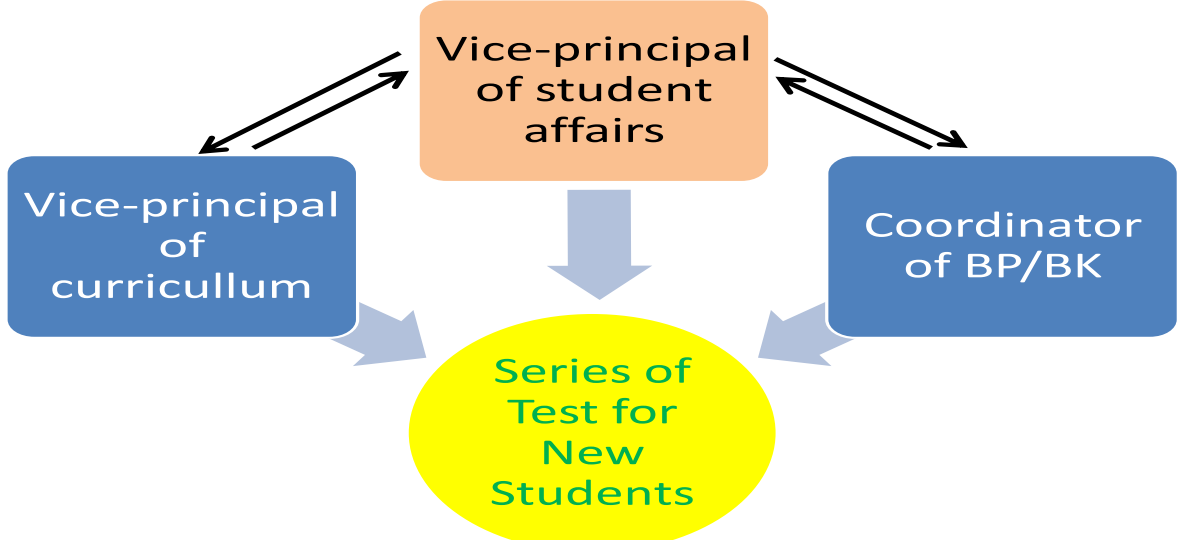

Vice-principal of curricullum has responsibility in the matter of writen test that consist of 100 questions with many kinds of subject. Even coordinator BP/BK has responsility in interview test.

Because of the pattern of managemant in student admission, almost every year MATU has incresing number of student.

Although the admission system which is every student can enter the madrasah is good, but unfortunately it is not supported well by the quantity of classrooms. For that reason every year there are still classes that boarded in the neighbours' building. This is not because there is no planning in deciding the number of students that will be accepted, but indeed this is the concept of admissions in MATU that follows the kiai's saying. But, however the madrasah has anticipated by preparing the additional classrooms from communities' buildings.

After admission, the next step in student affair management is giving orientation and gruoping the students into some classes.

\section{Orientation of New Students.}


Orientation of new students period in MATU usually called by MOSIBA (Masa Orientasi Siswa Baru/ new student orientation period). MATU has good orientation program that is in accordance with the original purpose of an orientation program, it is to introduce whatever related to madrasah programs to the new students such the laboratory, library, kind of extra-curicullar activities, curriculum program, counseling program and so on.

When students enter and start to study in MATU, means the madrasah must be introduced to the students because it is a new environmet for them. This kind of orientation is different with other shools that still impose orientation program that is complete with senior action in bullying the yunior.

In the matter of planning and organizing, MATU usually formulates the program firstly before implementing and forms a committee who must under-take the program. This means that MATU run the principles of management in running the orientation program. The following steps are what have done by MATU in managing the student orientation.

a. Forming the organizing committee of orientation (consists of chairman, secretary, treasurer, members, and equipment division)

b. Meeting of organizing committee to divide the tasks and equalize the measures.

c. Creating schedules and determining the resource persons

d. Evaluating the activities in orientation program.

e. Creating a report.

What interesting in orientation program of MATU as pesantren-based madrasah is separation of male and female students in implementing the orientation program.

Separation between male and female students activities is emphasized by the kiai. Though not mandatory, kiai highly recommend it. Means in certain situation or in an emergency the male and female students activities allowed to be merged.

As a pesantren-based madrasah, in orientation program MATU also introduce the pesantren tradition in reciting prayer "sa'altu", asma'ul husna and also tahlil". This kind of orientation makes this event distinctive with other shools orientation program.

From the table of schedule the researcher saw that the tutors selected to assist the students to recognize madrasah are in accordance with their respective fields. For example, the introduction of financial administration madrasah held by the treasurer, the introduction of guidance and counseling program presented by the staffs of $\mathrm{BP} / \mathrm{BK}$, and the material about noble character presented by two kia who hold the pesantrens in MATU environment (KH.Sofi Mubarok. AH hold Pesantren Sirojuth Tholibin and KH Abdul Wahab holds Pesantren AnNashriyyah). This shows that MATU not to carelessly in determining such kind of tutors in orientation.

After all MOSIBA activities done, the committe report to the principal. This is a kind of responsibility and the good way to evaluate the program in order to run better orientation program year by year.

\section{Grouping the Students}


Grouping the students based the interview with the vice-principal is under the responsibility of the committe of student admission. After MOSIBA, students are given the information about their classes. Male and female students are separated, follow the foundation policy, follow the kiai's saying to separate between male and female activities except in such in urgent situations.

Students not separated based on the level IQ. As revealed by Ali Mas'udi, the madrasah may not do the grouping students based on educational background, for example, who has strong background in religious education and who not. To classify them based on common background considered not possible by reason of limitation of resources both financial resources, time and human resources. Classifying studentsin different classses based on different capabilities will certainly affect the achievement standards that must be made. About this the principal said that the important is that students can follow, meaning not too behind with their friends and study. It is still impossible up to now if MATU sould classify the students based on the level of IQ. Beside the problem of limitation of the sources, it is also still thought, worried, whether classification will only make children in lower class even more feel inferior.

Guidance and Counseling Services (BP/BK) for Students.

MATU has counseling services program for students. This program is a part of student development program. Based on interview with Mr. Riyono and study of document, this program has writen plan used as guideline.

The organizing of this program can be seen in the following chart.

Figure 4: The Organizational Schema of Guidance and Counseling Program

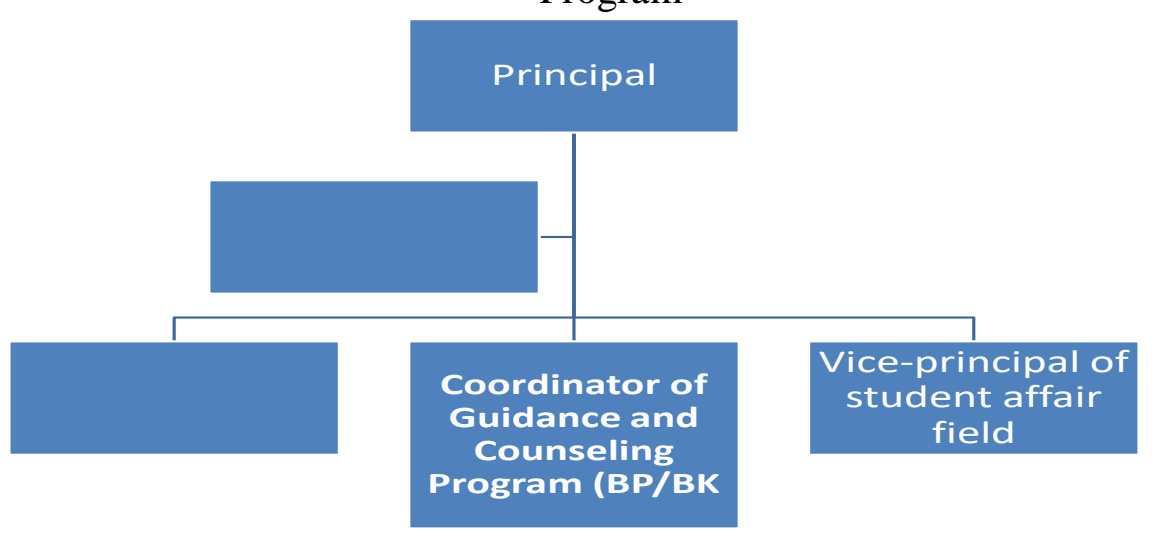

From the above chart we can see that coorditor of BP/BK (guidance and counseling) is directly responsible to the principal. This shows that the matter of counseling is counted as important thing aligned with curriculum management. In fact, even in the science of management guidance to the students included in the management of student, but MATU makes a separate line in structur to be more focused. This can be assumed that MATU gives special position to students' future. Target of counseling services are all students from class X to class XII.

$\mathrm{BP} / \mathrm{BK}$ conducts the counseling service related to the such following problems:

- Learning difficulties of students

- Career development of students

- Selecting the education programs and higher level 
- Social life problems of students

$\mathrm{BP} / \mathrm{BK}$ also formulates the competencies standart and basic competencies for each class and each semester. Competency standard created tiered.

In the first year $\mathrm{BP} / \mathrm{BK}$ arranges the program as a planing step. In the planing program, BP/BK decides what kind of program will be run, how is the method of guidance and counceling will be used and who will be responsible as counselor of each program. The pragram plan made in written form to be easy to be seen, recheked and evaluated regularly, up to where the program is run and if in accordance with a written plan or not.

In carrying out its functions, the coordinator of $\mathrm{BP} / \mathrm{BK}$ coordinate with many parties, they are: class guardians, vice-principal of students affair, viceprinciple of currricullum affair, vice-principapl of public relation, committe, and guardians of students, and Pondok Pesantren. Riyono said there is such kind of MOU with Pondok Pesantren. Like a typical teenager, although slightly, there must also student/santri who is not in accordance with the pesantren corridor. To anticipate such that case and also to realize the madrasah vision mission related students, madrasah and pesantren made a MOU.

The coordination done by division of BP/BK can be illustrated in the following chart.

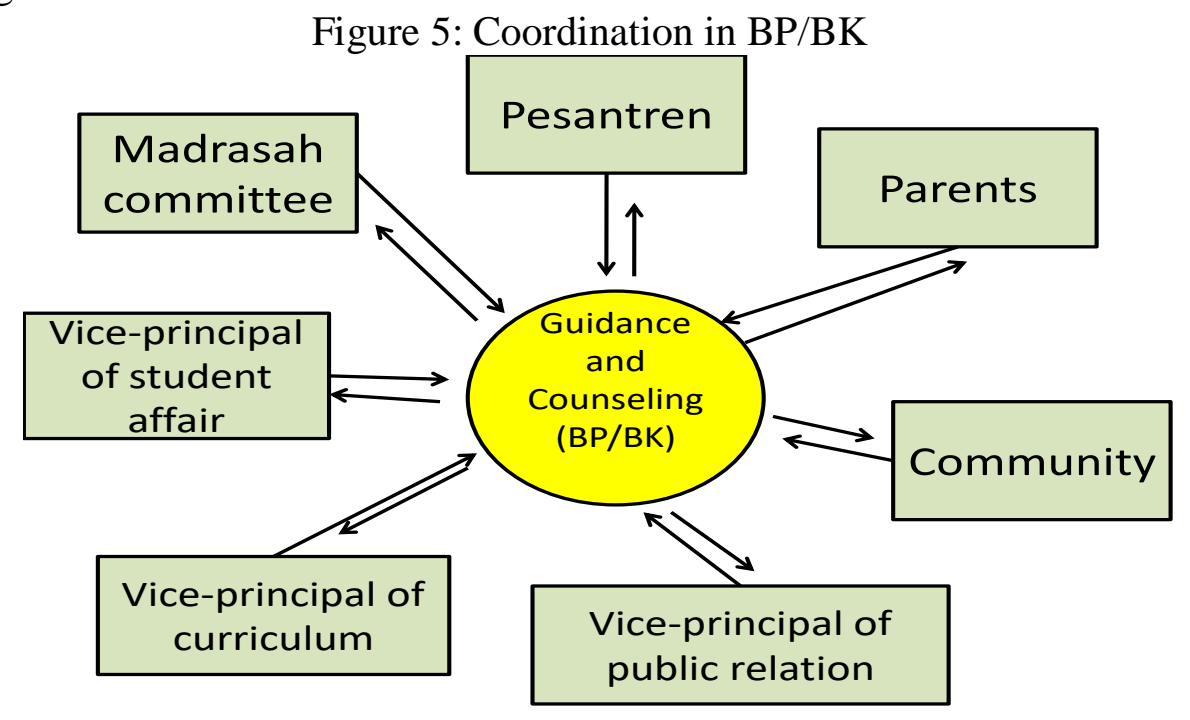

BP/BK coordinates with the vice-principal of student affairs in handling the matter of:

- Controlling of completeness of attribute, uniforms, accessories, hair, etc.

- Handling student discipline.

- Evaluation of student discipline.

- Handling the attendance of students.

Even with the vice-principal of curricullum, BP/BK coordinates in the matter of majors. With the vice-principal of public relationship, BP/BK coordinates about further study in colleges. BP/BK also coordinate with outside institutions to run its program. For example, BP/BK has done cooperation with police agency to make program of Counseling About Drugs and Juvenile Delinquency.

All programs have planned and documented in the form of written document. 
Forms of cooperation and coordination with pesantren, for example embodied in the following example. MATU will tell to Pesantren if there is santri in MATU who break the rules for example. MATU will confirm to make it easier in taking action to address them. For example, if there is a student who absent some days and say that the reason is sick, madrasah will ask to pesantren, is the student really sick or is it just an aliby. If there is a student who break the rule of pesantren and the penalty is he/she should be removed from the pesantren, so, the madrasah also should remove him/her (interview with the principal). But this not too rigid rule or policy. Means that $\mathrm{BP} / \mathrm{BK}$ considering many aspests before deciding the decision to drop the student out. There is an alternatif in this such kind of case, if there is a student that droped out from pesantren Sirojuth Tholibin but his/her parents still really want their son/daughter be changed by study in kiai's environment, that student can move from Pesantren Sirojuth Tholibin to Pesantren Hidayatush Shibyan. There are always stages in sanctions. Starting from the lightest form of reprimand sanction to the toughest sanction, it is excluded from the madrasah. The cases appear in MATU well documented in written document.

As pesantren-based madrasah, MATU always tries to build good character of students shown by having good manner. MATU gives sanction that likely differ from public school related to "bad" manner. The writer gives quotate for the word "bad" because the measure of good and bad manner may be different for each educational institution, between general schools and madrasah, even between madrasah and madrasah.

From the sample above it can be seen that MATU emphasizes in behaving with good manner. Drinking alcohol is a serious matter and has severe penalties. If there is student of MATU who get caught drinking even outside school hours and outside the madrasah he will be expelled. Such sanctions may be we don't find in public schools. This can be understood because in Islam, drinking alcohol forbidden in the Qur'an and Hadith. This is also because there is famous story related to moral destruction of a religionist earlier times after he fed liquor.

Besides giving guidance and counseling orally, face to face, BP/BK also coordinate with coordite with coordinator of bulletin to let the student get counseling related their problem through counseling rubric.

\section{Extra-curricular and Co-curricular}

MATU has extracurricular activities that are intended to develop students' talents. Those are scout, marching band, table tennis, soccer, rebana, Arabic club, English club, journalistic, and tilawatil Qur'an. Students can choose the extraactivities by theirselves Those activities performed on holiday (Friday). Since new academic year 2013/2014, MATU also offered "science club" and "math club". This run because of there is a consideration after evaluation that it sounds better if MATU hold science and math club after gaining achievement in those fields.

In terms of planning and organizing, the extra-curricullar program is pretty good, has a schedule, objectives and its own standards of competence, as well as regulated by the responsible parties, namely the field of student affairs vice principal and his staff.

Scout in MATU has objectives:

- Train the students to be independent.

- Develop a social life and care toward others. 
- Getting used to be disciplined in life.

Besides determine the goals of Scout program, there is also the formulation of competency standar and basic standar.

Besides the above activities, MATU has also journalistic activities in KRISTAL institution that publishes actively the monthly newsletter and magazine each year (usually in the end of year). The institution is already equipped with the Articles of Association and Bylaws (AD /ART) as an ideal foundation and legal basis. AD/ART contains chapters and articles related to the name, time and position of KRISTAL, principles, nature and status, objectives and functions, membership, meetings types, attributes, finance, change and transition, the editorial board, reorganization and others that are related.

Planning of KRISTAL has been implemented well. Already has program of work as outlined in a document complete with the type of activities to be held, the purposes, who is the executor, who are the targets and how is the budgets. However, from the documents, in KRISTAL budgeting not shown in the nominal range budgedteing.

KRISTAL also has a logical organizational structure. This means that the institution has implemented organizing functions within an organization. Unfortunately the implementation is lacking the active participation of ordinary members (students who are not editors).

\section{Development of Superior Achievement}

To stimulate student interest, the principal offers special agenda in holiday such as English course in Pare for a mont or two weeks. Another program to increase students' motivation is providing scholarships to the high achievers. Determination of the ranking in order to award these scholarships is made parallel with the purposes of enforcing the principle of justice.

Scholarships are not only given to those who rank first in school, but also who get championships in various fields of academic, arts, and sports.

MATU has management weakness in the matter of data collection and related records of student achievement. It has no complete data, means just has some parts and not sequential year-based. There are also many championships that have not been recorded. Documenting sometime seems unsefull but actually it can be usefull. For example can help in creating programs that involve the alumnus in future time to participate in development of students.

MATU also gives opportunity who want and able to develop their talent in the field of cinema and theater. MATU has ever participated in national short film competition LFP (Lomba Film Pendek) held by MEDP (Madrasah Education Development Center) in Bandung. MATU also participated in short film competition held by MEDP Grobogan. That competition followed by madrasahs in district Grobobogan. MATU became the first champion in the competition.

Those films prove that MATU tries to acomodate students' talent. There are still problems related, for example is the lack of ideas about the absence of an idea for a story with a lead actress. There is another problem that cause MATU so far has not been able to make development program of students' artistry talents through routine extra-curricullar activity. That problem is lack of funds.

It can be understood, why he did not bear to ask for dues from students. As stated by the principal, economic level of student trustee $80 \%$ is lower middle. Although there are many talented students who have an interest in the field of 
theater, but the limited funds led to the development of this potential becomes less than the maximum. Mr. Labib said that costs of production for a film is about two billion. two million. This figure looks small when in town, but in MA Tajul Ulum which is located in the village, two million is considered to be high numbers. This become an obstacle in the development of student potential.

MA Tajul Ulum also supports the students who have talent in calligraph. They can join in extra-cullicular of calligraph. MATU also always send them to be dellegetions in competitions of calligraph. Mr. Labib, who handles the extracullicular of calligraph, when asked, does MATU always send the delegetion in every competition of caligraphy. It indicates that MATU prioritizes experiences of students to develop their potentials. This is good way to motivate the students so they have more spirit to improve theirselves.

MATU often becomes champions in competitions related to the Arabic language, such as Arabic speech or writing scientific papers in Arabic. In Arabic competition, usually the way of presentation becomes a significant aspect of the assessment. With the frequent of becoming winner is evidence that education under pesantren such MATU is not only proficient in the Arabic written work, but also orally. However, the problem is that habituation to the Arabic language in everyday conversation is still lacking despite the fact that they know how is the Arabic of the things around them.

MATU is also not uncommon to win quiz competitions, short story writing competitions, art of tambourine music, and others.

Diversity of the championship accomplishments achieved shows that MATU have been trying to develop all students' superior potential.

\section{Tracking of Alumnus}

Based on Permendiknas Nomor 19 Tahu 2007 Tentang Standar Pengelolaan Pendidikan oleh Satuan Pendidikan Dasar dan Menengah in the field of student affair management, school or madrasah must perform the tracking of alumnus.

MATU is still weak in terms of alumnus management. There is no complete data about the output and outcome. When the researcher asked how many alumnus who continued study and where, madrasah could not answer with adequate data. From this interview and observation shows that the management related to the alumnus of MATU should be improved.

\section{Conclusion and Recommendation}

Based on the research, could be concluded that MATU has applied the management functions in admission of students, orientation of new students, counseling services for students, extra-curricular and co-curricular, development of superior achievement, but there is a big lack in the matter of tracking of alumnus, there is no adequate management related to alumnus. The supporting factors: attractive environmental condition because there are many pesantrens among the madrasah, cooperative society among the madrasah, cooperative pesantren parties, madrasah human resources that almost have educational background of pesantren. Inhibiting factors: lack of fund, the economic level of students' parents. Unadequate number of classrooms, the diversity if students' background, shortage of administrative staffs which affects student management. 


\section{Bibliography}

Ainurrafiq, Dawam and Ahmad Ta'arifin, 2005,Manajemen Madrasah Berbasis Pesantren, Jakarta: Lista Fariska Putra

Aqil, M. Hamid, 2010, Kebijakan Pimpinan Pondok Pesantren dalam Pengembangan Pendidikan Formal (Studi Kasus pada SMK di Pondok Pesantren "Nahdlatuth Thalabah" Kesilir Wuluhan Jember), magister thesis of Universitas Negeri Maulana Malik Ibrahim Malang

Arikunto, Suharsismi and Lia Yuliana, 2008, Manajemen Pendidikan, Yogyakarta: Aditya Media

Azizy Qodri, Pengantar: Memberdayakan Pesantren dan Madrasah dalam Ismail SM., Nurul Huda and Abdul Kholiq (eds), 2002, Dinamika Pesantren dan Madrasah, Yogyakarta: Fakultas Tarbiyah IAIN Walisongo and Pustaka Pelajar

Bush, Tony, 2003, Theories of Educational Leadership and Management Third Edition, Cromwell Press, Trowbridge

Daulay, Haidar Putra, Pemberdayaan Pendidikan Islam di Indonesia, Jakarta: PT. Rineka Cipta

Engkoswara and Aan Komariah, 2010, Administrasi Pendidikan, Bandung: Alfabeta

Engkoswara, 2001, Paradigma Manajemen Pendidikan Menyongsong Otonomi Daerah, Yayasan Amal Keluarga, Bandung

Nafis, Ahmadi H. Syukran, 2012, Manajemen Pendidikan Islam, Yogyakarta: LaksBang PRESSindo

Nata, Abuddin, 2012, Kapita Selekta Pendidikan Islam; Isu-isu Kontemporer tentang Pendidikan Islam, Jakarta: Raja Grafindo Persada

Nurkholis, 2003, Manajemen Berbasis Sekolah: Teori, Model dan Aplikasi, Jakarta: Grasindo

Saefullah, 2012, Manajemen Pendidikan Islam, Bandung: CV Pustaka Setia

Suharto, Toto, Konsep Dasar Pendidikan Berbasis Masyarakat, jurnal Cakrawala Pendidikan, November 2005, Th. XXIV, No. 3, hlm: 333

Syukur, Fatah, article of dissertation, 2011, Model Manajemen Madrasah Aliyah Efektif (Studi pada Tiga Madrasah Aliyah di Kudus), Semarang: Pascasarjana Unnes

Tim Dosen Administrasi Pendidikan Universitas Pendidikan Indonesia, 2011, Manajemen Pendidikan, Alfabeta, Bandung 